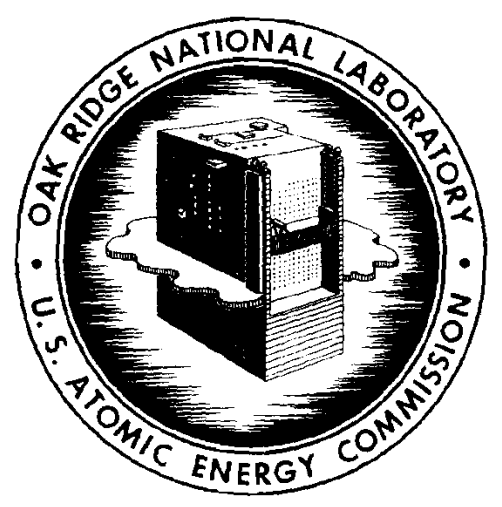

- PNTI

OAK RIDGE NATIONAL LABORATORY

operated by

UNION CARBIDE CORPORATION

for the

U.S. ATOMIC ENERGY COMMISSION

ORNL-TM-158 $\mathrm{i} / \mathrm{C}$

46

S. E. Dismuke

This document contains information of a preliminary nature and was prepared primarily for internal use at the Oak Ridge National Loboratory. It is subiect to revision or correction and therefore does not represent a final report. The information is not to be abstracted, reprinted or otherwise given public dissemination without the approval of the ORNL patent branch, Legal and Infor. mation Control Deportment. 


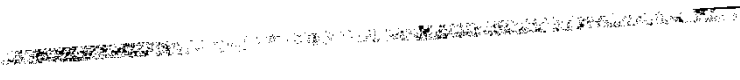

LEGAL NOTICE

This report was prepored as an occount of Government sponsored work. Neither the United States, not the Commission, nor any person acting on behalf of the Commission:

A. Mokes any warraniy or representation, expressed or implied, with respect to the accuracy, completeness, or usefulness of the information contained in this report, or thet the use of any informotion, opporatus, method, or process disclosed in this report may not infringe privotely owned rights; or

B. Assumes any liabilities with respect to the use of, or for damages esulting from the use of any information, apporatus, method, or process disclosed in this repart.

As used in the above, "persan ofting an behalf of the Commission" includes any amployee or contractar of the Commission, ar employee of such contector, to the oxtent that such employee or controctor of the Commission, or employee of such contractor prepores, disseminates, or provides access to, any information pursuant to his employment or contract with the Commission, or his employment with such contractor. 
ORNL TM-158

Contract No. W-7405-eng-26

OPERATIONS DIVISION

DIRECTIONS FOR THE FABRICATION OF A PROBE FOR THE MEASUREMENT

OF PLATE SPACING IN PIATE-TYPE FUEL ELEMENTS

S. E. Dismuke

DATE ISSUED

SPR 111962
OAK RIDGE NATIONAI IABORATORY
Oak Ridge, Tennessee
operated by
UNION CARBIDE CORPORATION
for the
U.S. ATOMIC ENERGY COMMISSION




\title{
DIRECTIONS FOR THE FABRICATION OF A PROBE FOR THE MEASUREMENT OF PLATIE SPACING IN PLATIE-TYYPE FUEL ELEMENTS
}

\author{
S. E. Dismuke
}

The measurement of the space between fuel plates in high-burnup MIR-type (Materials Testing Reactor) fuel elements is made by using eddycurrent techniques developed by Dodd and McClung. I The probe needs to be rugged in order to endure the rough treatment in a "hot cell" and yet sensitive enough to give results that are reliable to within 2 or 3 mils. The output is recorded by means of a chart recorder. This report was written in order to describe the probe and its fabrication.

The sensing section is supported near the end of a flattened stainless steel tube into which a rectangular hole (gage slot) has been cut to receive it. The sensing section consists essentially of two slightly bowed springs (flat spring steel, 0.0075 in. thick, 0.250 in. wide, and 2.400 in. long), the midsections of which protrude slightly above the upper and lower surfaces of the flattened tube. Each spring carries a section of a ball bearing as the contact point. (A very slight depression is milled into the section of the spring that will be in the center of the gage slot, in order to aid in the centering of the section of the ball bearing when it is soft-soldered into place.) It is these two slightly bowed springs (fixed at one end and free at the other, with their hemispherical contact points) that serve as expanding calipers, sensing variations in the spacing between adjacent plates. Essentially, the rest of the probe is a long handle to permit probing into the space between long fuel plates, and it is also a conduit for the electrical leads (the initial flattening of the tube is not sufficient to close it).

One spring carries the coil with its shield. The shield is an Armco iron ring (0.250 in. in diameter, $0.0075 \mathrm{in}$. thick, and $0.030 \mathrm{in}$. long) with a small cutout on the side next to the spring in order to bring the coil leads out. The ring is centered opposite the contact point and soft-soldered in place. The coil is then placed inside the ring and held in place with Eastman 9-10 cement. The coil is made in the following way: a coil of 100 turns, less than 0.235 in. in diam eter and less than $0.030 \mathrm{in}$. in thickness, is made with No. 40 enameled 
copper wire wound on a Teflon form; Eastman 9-10 cement is applied during winding in order to hold the wires together. The Teflon form is then carefully cut away to release the coil.

The probe is made of stainless steel tubing ( 0.313 in. in outside diameter, $0.025 \mathrm{in.}$ in wall thickness, and about $27 \mathrm{in.} \mathrm{Iong),} \mathrm{the} \mathrm{last}$ $25 \mathrm{in}$. of which has been initially flattened to about 0.100 in. The gage slot ( $0.260 \mathrm{in}$. wide and $2 \mathrm{in.}$ long) is then cut out, the cut for the slot being started about $I$ in. from the end of the flattened tubing. That terminal inch of the probe serves as an "entering wedge" for the probe and also as a "bumper" for the expanding calipers. The enteringwedge effect of the terminal inch of the probe is ensured by the removal of 0.010 of an inch of metal from both sides of the flattened tube. All sharp edges are rounded, and the prepared coil leads are put in place.

The lead wires for the coil are made from No. 26 bare copper wire that has been rolled down to approximately 0.003 in., using several anneals. The wires are then carefully placed on 0.006-in.-thick Scotch electrical tape No. 27 that has been cut to about 0.400 in. in width; a similar piece of tape is then placed on top. This "sandwiching" of the wires between the two strips of tape serves to insulate the wires.

The lead wires are then drawn into the flattened (but not completely closed) tube to within about $0.5 \mathrm{in}$. of the position that the coil will be in, that is to say, to about the middle of the 2-in.-long gage slot. At the point of entry of the wires into the gage slot, two pieces of mica ( $0.002 \mathrm{in.} \mathrm{thick,} 0.400 \mathrm{in}$. wide, $0.500 \mathrm{in}$. long) are sandwiched about the wires and pushed about 0.200 in. into the tube in order to prevent mechanical damage to the wires as the probe is further flattened, a later step.

A shim 0.020 in. thick and full width of the tube is inserted from the probe end of the tube as far as the end of the tape in the gage slot. Two other shims, $0.010 \mathrm{in.} \mathrm{thick,} \mathrm{are} \mathrm{inserted} \mathrm{on} \mathrm{either} \mathrm{side} \mathrm{of} \mathrm{the}$ first shim but just barely into the gage slot. (Recall that the first shim went halfway into the gage slot.)

The entire flattened portion of the probe is then flattened to its final thickness of 0.070 in. The shims are pulled out, and 0.010-in. 
recesses at the handle end of the gage slot are milled out on both sides of the probe. These recesses receive the fixed ends of the springs; they are fixed into place by soft soldering.

The springs must be bent into the slot slightly just after the attachment point, then curved out to the gage point, then back down and straightened out again a short distance before they go into the flattened tube at the opposite end of the gage slot. After bending into shape, the springs will look something like this: $\frown$.

The spring carrying the coil assembly is mounted just as the other spring is, but a little more needs to be done, as follows: A small portion of the electrical tape is peeled back, connections are made to the fine coil wires (leave extra wire here to allow for flexing), the tape is then put back in place, and the upper spring is soldered in place. Care should be taken to position the ball-bearing sections directly opposite each other. The last $0.250 \mathrm{in}$. of the gage section of the probe is then completely flattened and welded.

A two-wire shielded cable is firmly attached to the unflattened end of the probe and then attached to a modified Wheatstone bridge, from which the output is fed into a chart recorder. In the present unit a Dermitron (ref 2) and a Speedomax H (ref 3) are used.

The Dermitron recorder is modified by putting a low-resistance tenturn pot in series with the "balance" pot, and knobs that can be locked are put on both "balance" pots and the "sensitivity" control. A switch is put on the meter leads in order to switch from the meter to a connection on the back of the instrument for the chart-recorder connections.

The chart recorder is modified so that the chart speed corresponds to the scanning rate of the probe.

The operating procedure consists in placing the fuel element on a mill table, inserting the probe between the fuel plates, adjusting the position of the mill table so that the probe handle can be clamped to a fixed post, then moving the mill table away from the clamp at a constant rate. At the same time that the mill travel starts, the recorder-chart drive is started.

The dimensions of the components of the probe are chosen to give the most accurate results for a nominal plate spacing of 0.125 in. Very 
little error will result if the probe is not rotated more than $10.5^{\circ}$ from the normal in those elements that have flat plates and if the probe is not rotated more than $9.25^{\circ}$ from the normal in MIR-type fuel elements, which have curved fuel plates.

The range of the probe is from 0.090 in. to 0.160 in. Calibrate by using a special gage as shown in the sketches. Inaccurate calibration will result unless the gaging area is wider than the probe.

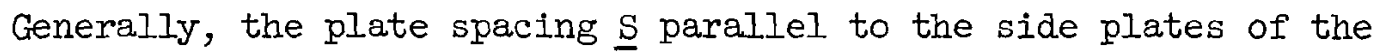
fuel element is required in MIR-type fuel elements; so a correction factor must be applied. In this type of element, the actual plate spacing $\underline{S}$ is approximately equal to the gage reading $G$ divided by the cosine of the angle which the center of the probe makes with the vertical centerline axis of the lower plate as measured at the radius of curvature (i.e., $\cong G / \cos \theta$ ). In the case when the probe is touching the side plate, that angle will be $12^{\circ} 54^{\prime}$, and the correction becomes $\underline{S} \cong \mathrm{G} / 0.9748$. (Recall that the probe is designed to measure the normal separation between plates, while the spacing that is required to be measured is that which is parallel to the side plates of the fuel element. )

\section{ACKINOWLEDGMENT}

The author wishes to acknowledge the assistance of J. F. Odom in the development work of the probe.

\section{REFERENCES}

I. C. V. Dodd and R. W. McClung, Fuel-Element Coolant Channel and Other Spacing Measurement by Eddy-Current Techniques, paper presented at the Annual Meeting of the American Nuclear Society, Pittsburgh, Pa., June 6, 1961.

2. The Dermitron unit is manufactured by the Unjt Process Assemblies, Inc., Woodside 77, New York.

3. Speedomax $\mathrm{H}$, model $\mathrm{S}$, 0 to $10 \mu \mathrm{v}$, 1-sec balancing speed; manufactured by Leeds \& Northrup Co., 4901 Stenton Ave., Philadelphia 44, Pa. 
UNCLASSIFIED

ORNL-LR-DWG 66900

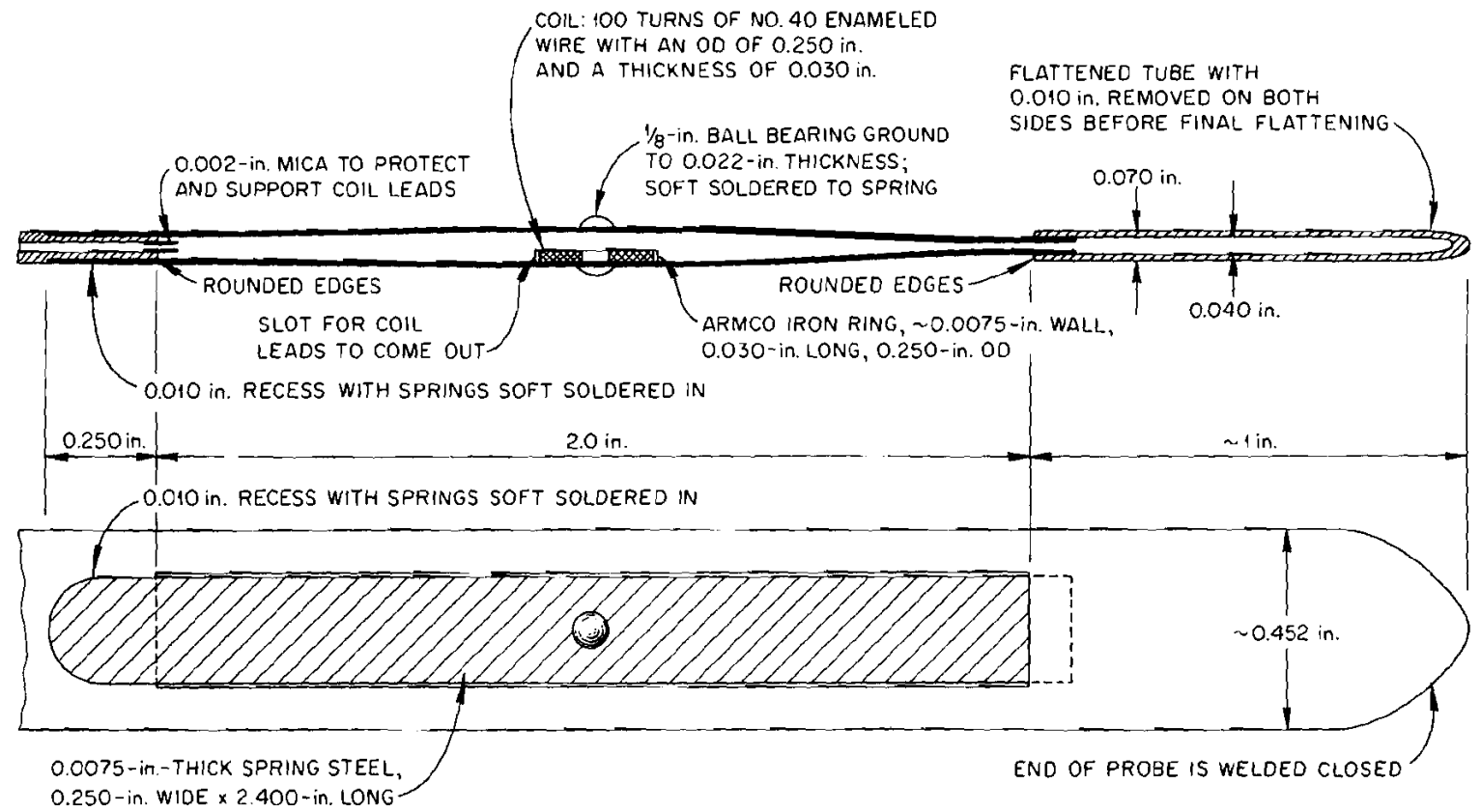

PROBE IS MADE FROM 0.313 -in.-OD STAINLESS STEEL TUBING WITH

0.025-in. WALL THICKNESS; FLATTENED TO 0.070 in., WITH COIL LEADS INSIOE

Delail Sketch No. 1.

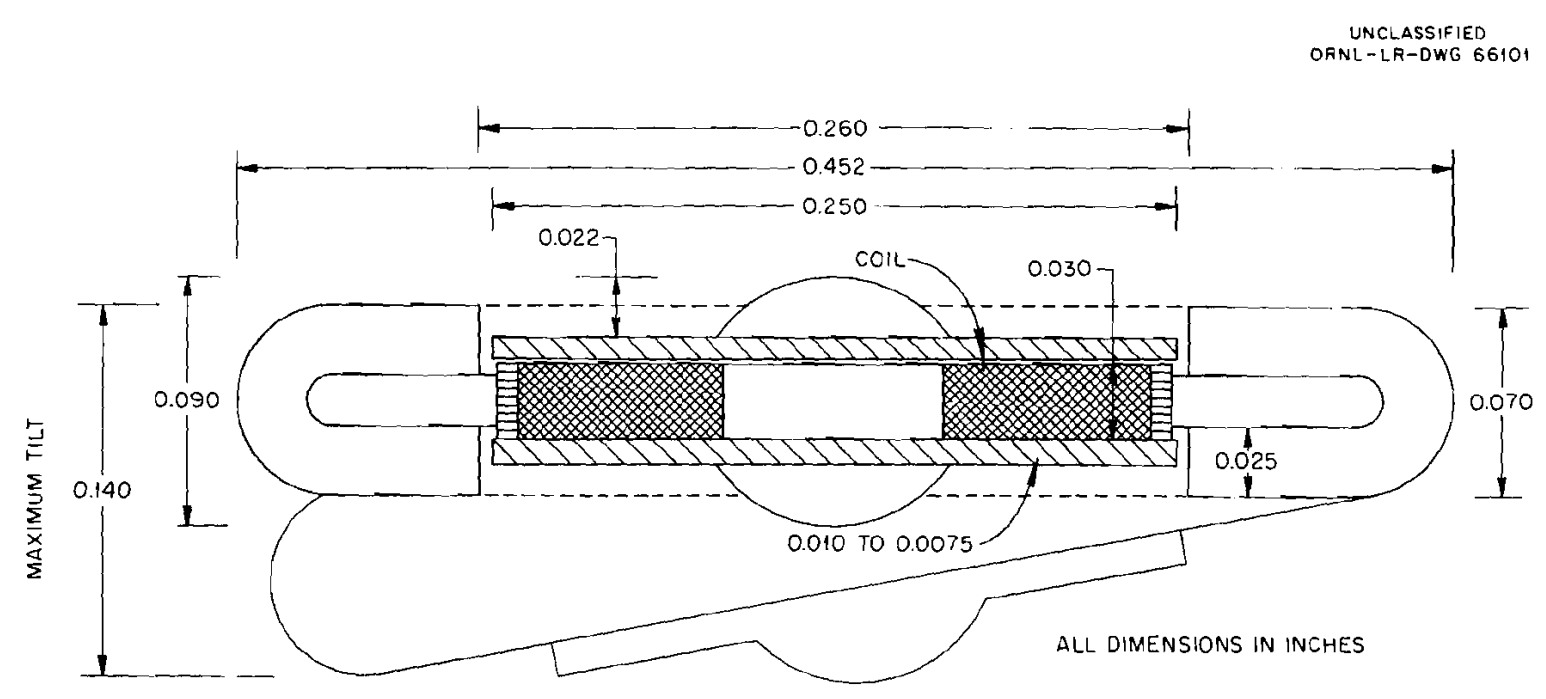

Delail Sketch No. 2. Cross Secrion Through Gage Position 


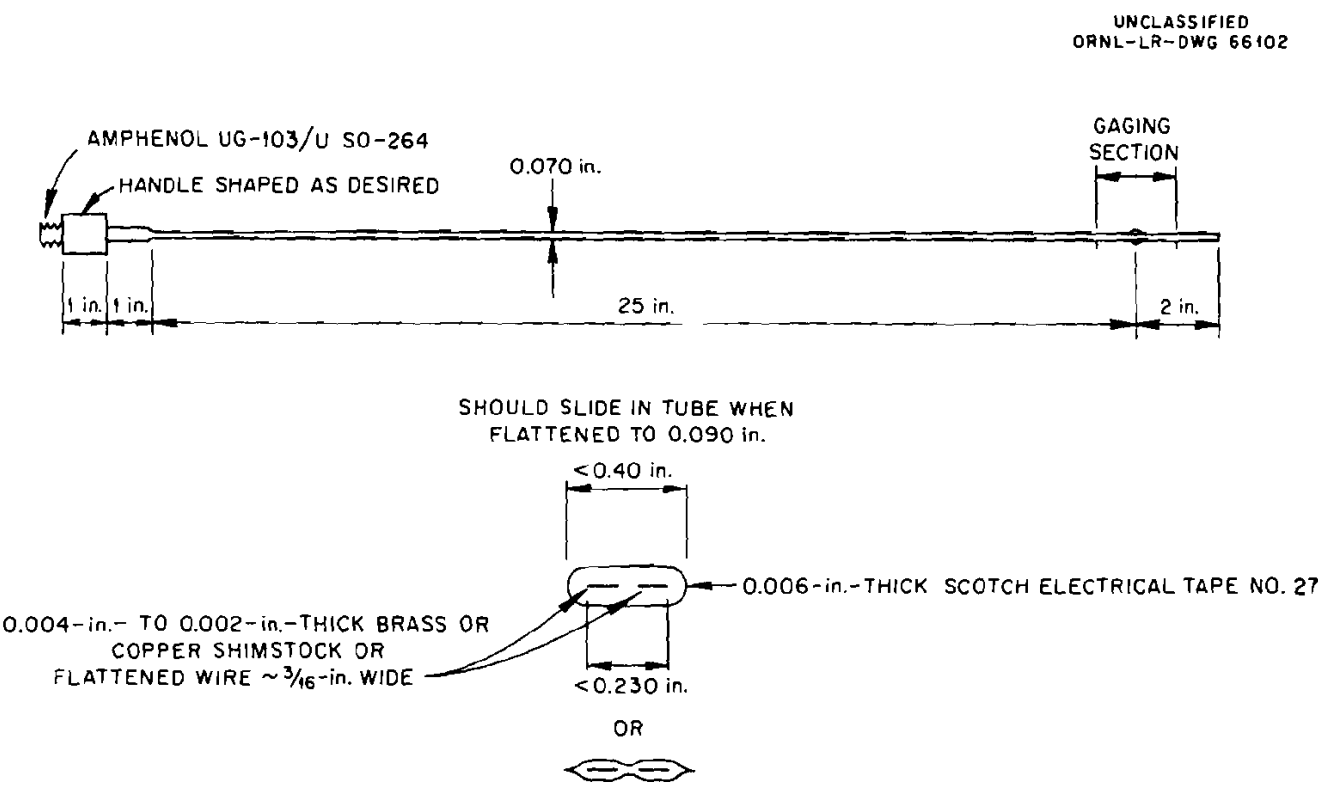

LEAD WIRE FOR COIL TO PLUG TO BE PLACED

INSIDE TUBE BEFORE FINAL FLATTENING

Probe for Plote-Spocing Meosurements

UNCLASSIFIED
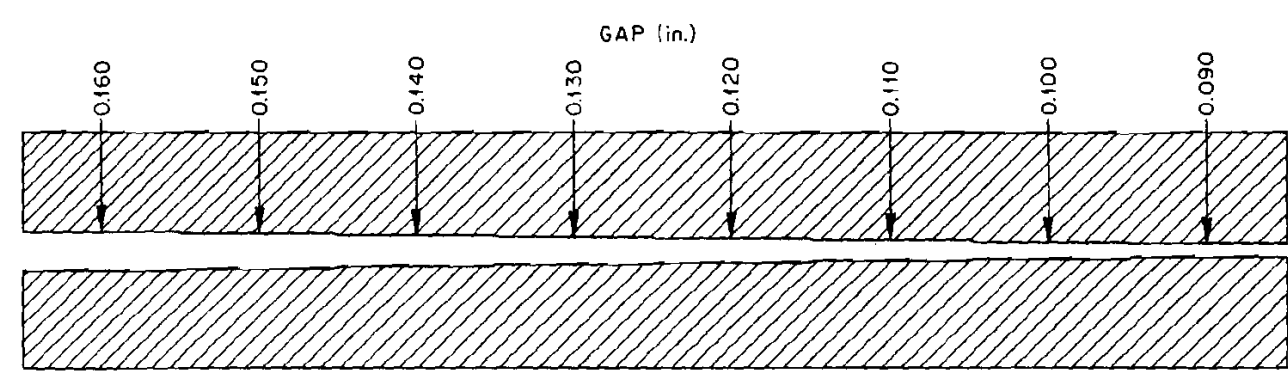

SECTION

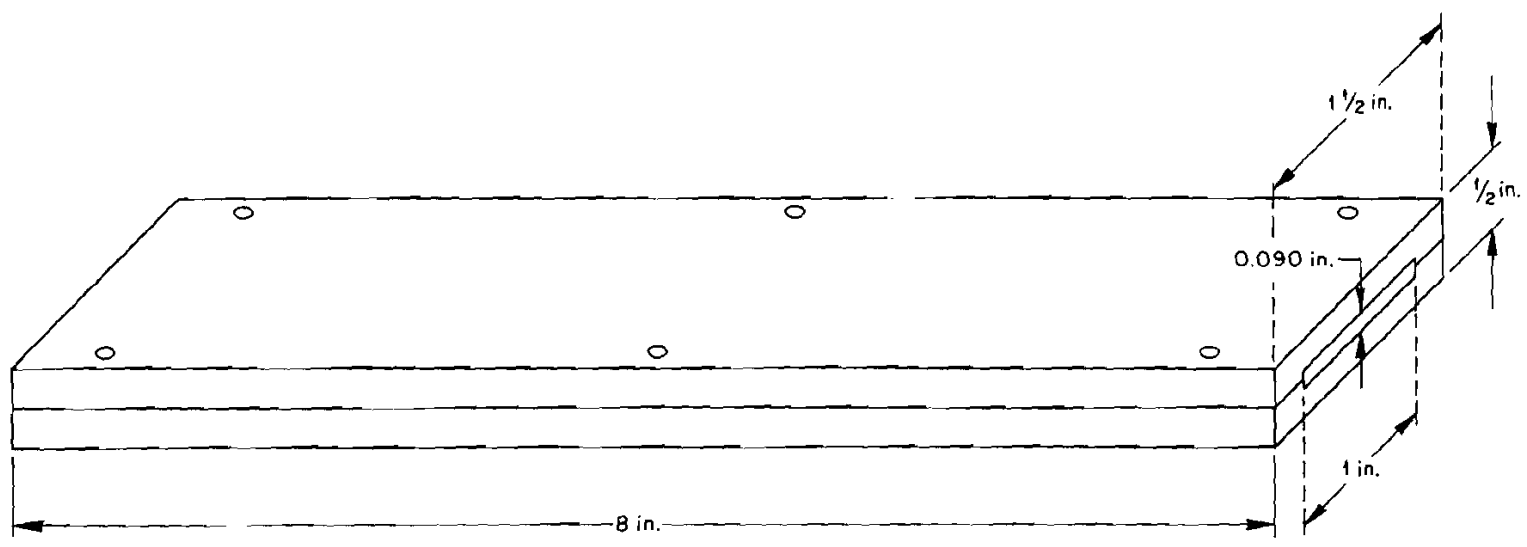

Calibration Goge (Moterial: Aluminum) 
INTERIAL DISTRIBUTION

1-15. S. E. Dismuke

16-35. I. D. Schaffer

36. C. V. Dodd

37. J. A. Cox

38-39. Central Research Library

40. ORNI - Y-12 Technical Library

Document Reference Section

41-45. Laboratory Records Department

46. Laboratory Records, ORNI R.C.

EXTERNAL DISTRIBUTION

47-61. DTIE

62. J. G. Ronsick, Phillips Petroleum Company

63. S. C. Furman, GE, Vallecitos

64. Division of Research and Development, AEC, ORO 
